\title{
PENINGKATAN HASIL BELAJAR SISWA DENGAN METODE KOOPERATIF TIPE GROUP INVESTIGATION MATA PELAJARAN PKN KELAS V SD 165730 KOTA TEBING TINGGI
}

\author{
Onomdina \\ Surel: onomdinaspd@gmail.com
}

\begin{abstract}
This purposes of this research is to improve learning result on PKn subject through cooperative method group investigation type. This classroom action researchconducted by 2 cycles of the four phases: planning, implementation, observation, reflection. The subjects were students from class $V, S D N$ 165730 Tebing Tinggi which amounted to 33 students. This study used a qualitative descriptive analysis technique. The results showed that the use of the cooperative method group investigation typeof PKn subjects can improve student learning result characterized by increased mastery learning students, namely pre-cycle $(66,67 \%)$, the first cycle $(72,72 \%)$, cycle II $(90,90$ $\%)$ and complete learn the clasical equal to 90,90\%.
\end{abstract}

Keywords :Cooperative, Group Investigation, Learning Result

\begin{abstract}
ABSTRAK
Penelitian ini bertujuan untuk meningkatkan hasil belajar siswa mata pelajaran PKn melalui metode cooperativetipe group investigation. Penelitian tindakan kelas ini dilaksanakan sebanyak 2 siklus dengan empat tahapan yaitu : perencanaan, pelaksanaan, observasi, refleksi. Subjek penelitian ini adalah siswa Kelas V SD N 165730 Tebing Tinggi sebanyak 33 siswa. Penelitian ini menggunakan teknik analisis dekriptif kualitatif. Hasil penelitian menunjukkan bahwa penggunaan metode cooperative tipe group investigation mata pelajaran PKn dapat meningkatkan hasil belajar siswa yang ditandai dengan peningkatan ketuntasan belajar siswa, yaitu pra siklus $(66,67 \%)$, siklus I $(72,72 \%)$, siklus II $(90,90 \%)$ dan dinyatakan berhasil ssecara klasikal 90,90\%.
\end{abstract}

Kata Kunci : Kooperatif, Group Investigasi, Hasil Belajar

\section{PENDAHULUAN}

Model pembelajaran klasikal dengan ceramah menjadikan kurang bermakna, karena partisipasi pengajar terlalu mendominasi. Setisp proses pembelajaran menuntut terjadinya interaksi tinggi antara pengajar dan peserta didik. Disamping itu, penajaman kreativitas siswa terhadap materi lebih diutamakan, karenanya perlu dikembangkan berbagai kegiatan belajar dengan melibatkan peran aktif siswa dalam proses kegiatan mengajar.

PKn merupakan salah satu mata pelajaran yang memenuhi tuntutan tujuan pendidikan dasar yaitu untuk mengembangkan kehidupan siswa sebagai pribadi, anggota masyarakat, warga negara dan anggota umat manusia. Mata 
pelajaran ini berfungsi sebagai pendidikan nilai, yaitu mata pelajaran yang mensosialisasikan dan menginternalisasi-kan nilai-nilai pancasila/ budaya bangsa seperti yang terdapat pada kurikulum PKn SD (Ruminiati 2007: 1,30).

PKn merupakan pendidikan untuk memberikan bekal awal dalam bela negara yang dilandasi oleh rasa cinta kepada tanah air, kesadaran berbangsa dan bernegara, berkeyakinan atas kebenaran idiologi pancasila dan UUD 1945 serta kerelaan berkorban untuk kepentingan bangsa dan negara (Ittihad, 2007: 1, 37). Berdasarkan beberapa pendapat di atas, penulis menyimpulkan bahwa PKn merupakan mata pelajaran yang berkaitan erat dengan pendidikan afektif yang berpengetahuan bela negara. PKn juga dikatakan sebagai pendidikan awal bela negara, idiologi pancasila dan UUD 1945, naturalisasi, dan pemerolehan status warga negara.

Sekolah dasar sebagai bagian dari pendidikan dasar memiliki tujuan yang mengacu pada tujuan pendidikan nasional yaitu untuk memberikan bekal kemampuan dasar kepada siswa untuk mengembangkankehidupannya sebagai pribadi, anggota masyarakat, warga negara dan anggotaumat manusia, serta mempersiapkan siswa untuk mengikuti pendidikan menengah (Mikarsa, 2007: 1-12).

Berdasarkan hasil pengamatan peneliti pada bulan September, peneliti menemukan beberapa masalah pada pembelajaran PKn di Kelas V yang belum berlangsung secara optimal. Permasalahan tersebut berasal aktivitas siswa selama pembelajaran serta hasil belajar siswa yang masih dibawah Kriteria Ketuntasan Minimal (KKM). Hal itu terlihat pada saat kegiatan diskusi kelompok berlangsung hanya beberapa anggota kelompok saja yang memperhatikan dan bertanggung jawab dalam mengerjakan tugas kelompok, tidak semua siswa ikut aktif dalam mengerjakan tugas, sehingga proses diskusi kelompok menjadi kurang optimal karena hanya beberapa anggota kelompok atau siswa saja yang bekerja sedangkan yang lain tidak memperhatikan bahkan tidak mengerti apa yang sedang didiskusikan sampai pembelajaran berakhir.

Salah satu cara untuk mengukur efektivitas pembelajaran adalah melaluievaluasi yang dilihat dari pencapaian KKM. Hasil penilaian ulangan harian siswa Kelas V SD 165730 menunjukkan bahwa 11 siswa dari 33 siswa $(33,33 \%)$ belum mencapai standar KKM. Hanya 22 siswa $(66,67 \%)$ yang nilainya diatas KKM. Pada mata pelajaran PKn, didapatkan bahwa pencapaian nilai terendah 50 dan ketercapaian nilai tertinggi adalah 85. Hasil belajar siswa yang rendah dapat digunakan sebagai indikator bahwa pembelajaran PKn belum berhasil. Untuk mengatasi masalahtersebut, peneliti berkolaborasi dengan observer 
menetapkan alternatif penelitian tindakan kelas untuk meningkatkan kualitas pembelajaran PKn melalui metode kooperatiftipe group investigation.

\section{Group investigation}

merupakan salah satu metode dari pembelajaran kooperatif. Metode ini sering dipandang sebagai metode paling kompleks dibandingkan dengan metode lain dalam pembelajaran (Mcklar, 2010).Menurut pendapat Jacobs et.al (dalam Wiryandi, 2010:24) menyatakan konsep penting yang harus diperhatikan dalam pendekatan GI yang bersifat humanis adalah : (1) menghindarkan evaluasi yang menggunakan tes, (2) learning by doing, (3) membangun motivasi intrinsic, (4) mengutamakan pilihan siswa, (5) memperlakukan siswa sebagai orang yang bertanggungjawab, (6) pertanyaanpertanyaan terbuka, (7) mendorong rasa saling menghormati dan saling membantu, dan (8) membangun konsep diri yang positif.

Model pembelajaran kooperatif tipe group investigasi dapat dipakai guru untuk mengembangkan kreativitas siswa, baik secara perorangan maupun kelompok. Model pembelajaran kooperatif dirancang untuk membantu terjadinya pembagian tanggung jawab ketika siswa mengikuti pembelajaran dan berorientasi menuju pembentukan manusia sosial (Mafune, 2005). Model pembelajaran kooperatif dipandang sebagai proses pembelajaran yang aktif, sebab siswa akan lebih banyak belajar melalui proses pembentukan (contructing) dan penciptaan, kerja dalam kelompok dan berbagi pengetahuan serta tanggung jawab individu tetap merupakan kunci keberhasilan pembelajaran.

Berdasarkan permasalahan tersebut maka penulis tertarik untuk meneliti metode ini karena siswa dapat terlibat secara aktif dalam kegiatan proses pembelajaran, mengembangkan disiplin intelektual dan keterampilan berpikir dengan memberikan pertanyaan -pertanyaan dan mendapatkan jawaban atas dasar rasa ingin tahu mereka khususnya pada mata pelajaran $\mathrm{Pkn}$.

Berdasarkan uraian pada latar belakang masalah, maka dapat dirumuskan permasalahan sebagai berikut: "Apakah dengan menggunakan pembelajaran metode kooperatif tipegroup investigation meningkatkan hasil belajar PKnsiswa Kelas V SD Negeri 165730 kota Tebing Tinggi Tahun pelajaran 2017/2018?"

Tujuan dari penelitian ini adalah untuk meningkatkan hasil belajar PKn siswa Kelas V SD Negeri 165730kota Tebing Tinggi tahun pembelajaran 2017/2018 melalui metode kooperatif tipe group investigation.

\section{METODE PENELITIAN}

Penelitian ini diawali dengan pengajuan judul tentang penelitian yang akan dilaksanakan. Subyek penelitian adalah siswa Kelas V SD 
Negeri 165730 Tebing Tinggi semester I tahun 2017/ 2018 dengan jumlah siswa sebanyak 33 orang dengan 16 orang laki-laki dan 17 orang perempuan. Sumber data yang digunakan adalah siswa dan teman sejawat. Pada Penelitian tindakan kelas data yang dikumpulkan dapat berbentuk kuantitatif maupun kualitatif.Penelitian tindakan kelas tidak menggunakan uji statistik, tetapi dengan deskriptif. Data kuantitatif yang berupa nilai dianalisis dengan menggunakan analisis deskriptif komparatif yaiu membandingkan nilai tes kondisi awal, nilai tes setelah siklus I dan II yaitu nilai dari hasil ulangan harian siswa Kelas V SD Negeri 165730 pada siklus I dan II. Komponen pengajaran metode kooperatiftipe group investigation yang sangat data kualitatif yang berupa observasi kegiatan guru, dan sisa serta data kuantitatif yang berupa nilai hasil ulangan harian siswa Kelas V. Model penelitian tindakan kelas yang digunakan peneliti adalah system spiral refleksi diri yang dikembangkan oleh Kemmis dan Taggart (1990: 11) yang dimulai dengan perencanaan, tindakan, pengamatan, dan refleksi.

Sebelum mengadakan penelitian peneliti menyusun rumusan masalah, tujuan dan membuat rencana tindakan, termasuk di dalamnya RPP, LKS, observasi, instrumen penelitian dan perangkat pembelajaran.

\section{Siklus I}

Dengan bimbingan guru, siswa membentuk kelompok secara heterogen. Guru melakukan pembelajaran di dalam kelas dengan menggunakan panduan perencanaan yang telah dibuat. Siklus I dilakukan pada tanggal 14 Oktober 2017. Penerapan metode kooperatiftipe group investi gationdilakukan dengan menugaskan kepada masingmasing kelompok untuk mendiskusikan materi yang dibahas.Materi yang dibahas pada siklus ini adalah mengenal lembagalembaga sistem pemerintahan kabupaten, kota, dan provinsi. Setiap anggota kelompok merencanakan mengenai hal-hal yang berkaitan dengan materi, siapa dan melakukan apa serta tujuan mempelajari topik itu. Pada saat kegiatan pembelajaran berlangsung guru sebagai peneliti dibantu oleh para observer lainnya untuk melakukan pengamatan, mendokumentasi kegiatan, selain itu peneliti bertindak sebagai fasilitator, motivator dan sekaligus sebagai pengamat.

\section{Siklus II}

Dengan bimbingan guru, siswa membentuk kelompok secara heterogen. Siklus II dilakukan pada tanggal 21 Oktober 2017. Guru melakukan pembelajaran di dalam kelas dengan menggunakan panduan perencanaan yang telah dibuat. Penerapan metode kooperatiftipe group investigation dilakukan dengan menugaskan kepada masingmasing kelompok untuk 
mendiskusikan materi yang dibahas.Guru melakukan pembelajaran didalan kelas dengan menggunakan panduan perencanaan yang telah dibuat. Materi yang diajarkan guru yaitu menggambarkan struktur organisasi kabupaten, kota, dan provinsi. Pada Siklus kedua ini juga, suasana pembelajaran masingmasing kelompok di lingkungan sekolah dikondisikan agar tidak terlalu formal, maksudnya siswa bebas mengemukakan pendapatnya tentang materi ajar sesuai dengan kompetensi dasar yang ingin dicapai.

Pengamatan dilakukan peneliti sendiri dan dibantu oleh pengamat dan mencatat proses penerapan teknik pengajaran kolaborasi. Observasi adalah suatu cara untuk memperoleh data dengan jalan mengadakan pengamatan langsung secara sistematis terhadap suatu objek tertentu yang dicatat dalam catatan observasi (lembar observasi). Pengamatan yang dimaksud adalah pengamatan dengan seluruh alat indera (Arikunto,1998:128).

Peneliti mengkaji, melihat dan mempertimbangkan hasil atau dampak dari tindakan yang dilakukan berdasarkan lembar pengamatan yang diisi oleh pengamat. Tahapan ini dilakukan secara berkesimbungan sehingga ditemukan hasil yang optimal Kegiatan pada tahap refleksi meliputi kegiatan menganalisis, memahami dan membuat kesimpulan berdasarkan hasil observasi setiap siklus. Menemukan kelebihan dan kelemahan tindakan perbaikan pembelajaran. Hasil analisis data yang dilaksanakan pada tahap ini akan dipergunakan untuk menemukan kelebihan dan kelemahan diri dalam merancang dan melakukan tindakan sebagai acuan.

Metode pengumpulan data penelitian ini adalah tertulis dan observasi. Penelitian ini dikatakan berhasil apabila siswa telah memperoleh nilai ketuntasan secara klasikal minimal $85 \%$ dari jumlah siswa.

\section{HASIL PENELITIAN DAN PEMBAHASAN}

Hasil penelitian tindakan kelas menunjukkan bahwa pengamatan yang dilakukan oleh mitra kolaborasi dan peneliti pada aktivitas guru dan siswa melalui penerapan metode kooperatif tipe group investigation pada mata pelajaran PKnKelas V SD Negeri 165730 Tebing Tinggi dapat dilihat pada tabel 1 yaitu sebagai berikut :

\section{Tabel 1. Peningkatan Hasil Belajar Siswa Pra Siklus, Siklus I dan II}

\begin{tabular}{cccc}
\hline \multicolumn{3}{c}{ Peningkatan Hasil Belajar } & \\
\cline { 1 - 3 } $\begin{array}{c}\text { Pra } \\
\text { Siklus }\end{array}$ & $\begin{array}{c}\text { Siklus } \\
\text { I }\end{array}$ & $\begin{array}{c}\text { Siklus } \\
\text { II }\end{array}$ & Keterangan \\
\hline 22 & 24 & 30 & $\begin{array}{c}\text { Jumlah Siswa } \\
\text { Lulus }\end{array}$ \\
\hline 66,67 & 72,72 & 90,90 & $\begin{array}{c}\text { Persentase } \\
\text { Ketuntasan } \\
\text { Belajar (\%) }\end{array}$ \\
\hline
\end{tabular}

Berdasarkan pengamatan peneliti dari tindakan pra siklus, siklus I dan II terjadi peningkatan hasil belajar pada jumlah siswa dan persen ketuntasan belajar secara klasikal. Hal ini dapat dilihat dengan 
peningkatan jumlah siswa dari 22 siswa yang tuntas belajar pada pra siklus menjadi 30 siswa yang tuntas belajar melalui metode kooperatif tipe group investigation siswa Kelas V SDNegeri 165730 Tebing Tinggi.

Kemampuan siswa pada pra siklus dalam memahami sistem pemerintahan di Indonesia dari tingkat desa sampai dengan tingkat pusat masih rendah. Aktivitas siswa pada pra siklus dalam mendengarkan/ memperhatikan penjelasan guru, mengerjakan tugas yang diberikan guru, keantusiasan siswa mengikuti pelajaran, menuliskan dan menyampaikan hasil percobaan, bekerja sama dan berdiskusi dengan kelompok juga masih rendah maka dari itu dilakukan penelitian siklus I.

Sebelum dilakukan metode cooperative tipe group investigationpada saat pembelajaran, siswa yang aktif cenderung sedikit sedangkan lebih banyak didominasi oleh siswa yang kurang aktif, sehingga dari sana akan mempengaruhi aktivitas belajar siswa. Adapun ciri-ciri yang menyebabkan aktivitas belajar siswa rendah yaitu dapat dilihat dari kurangnya minat siswa untuk mengancungkan tangan dalam menanggapi pertanyaan yang diberikan oleh guru, selain itu siswa kurang aktif untuk bertanya dalam proses pembelajaran, sehingga dari hal tersebut akan berpengaruh terhadap rendahnya hasil belajar siswa khususnya pada pelajaran PKn

Hasil ulangan siswa pada pelajaran PKn di Kelas Vsudah tergolong cukup, yaitu memperoleh rata-rata 72, sedangkan Kriteria Kelulusan Minimal (KKM) yang harus dicapai siswa adalah 70 . Namun, masih perlu dilakukan peningkatan hasil belajar. Dari 33 orang siswa yang mengikuti ujian pada pelajaran PKn hanya 24 orang siswa atau $72,72 \%$ yang berhasil mendapatkan nilai di atas nilai 70 , sedangkan 9 orang siswa atau $27,27 \%$ mendapat nilai di bawah nilai 70.Hasil tersebut menunjukkan bahwa pada siklus pertama secara klasikal siswa belum tuntas belajar, karena siswa yang memperoleh nilai $\geq 70$ hanya sebesar $72,72 \%$ lebih kecil dari persentase ketuntasan yang dikehendaki yaitu sebesar $85 \%$.

Meskipun demikian, terjadi peingkatan hasil belajar siswa dari pra siklus ke siklus I walaupun hasilnya belum sesuai dengan indikator keberhasilan. Hal ini membuktikan bahwa dengan penerapan metode kooperatif tipe group investigation dapat meningkatan hasil belajar siswa Kelas V SD 165730. Pendapat ini sesuai dengan pernyataan Mafune (2005) yang menyatakan bahwa model pembelajaran kooperatif tipe group investigasi dapat dipakai guru untuk mengembangkan kreativitas siswa, baik secara perorangan maupun kelompok. Model pembelajaran kooperatif dirancang untuk membantu terjadinya pembagian tanggung jawab ketika siswa mengikuti pembelajaran dan berorientasi menuju pembentukan manusia sosial. 
Pada tabel 1, metode pembelajaran kooperatif tipe group investigation pada siklus II diperoleh nilai rata-rata ulangan harian siswa adalah 77,68 dan ketuntasan belajar mencapai $90,90 \%$ atau ada 30 siswa dari 33 siswa sudah tuntas belajar. Hasil tersebut menunjukkan bahwa pada siklus kedua secara klasikal sudah tuntas belajar, karena siswa yang memperoleh nilai $\geq 70$ sebesar 90,90\% sudah memenuhi kriteria dari persentase ketuntasan yang dikehendaki yaitu sebesar $85 \%$.

Pada siklus II, siswa sudah dapat bekerja sama dengan teman sekelompoknya. Setiap kelompok merencanakan mengenai pembagian tugas tiap anggota dan menentukan tujuan investigasi. meskipun masih ada siswa yang pasif namun hal ini masih dianggap baik oleh peneliti. Siswa dapat menyelesaikan tugas dengan baik. Setiap anggota kelompok mencatat hal-hal penting yang terkait dengan sub pokok yang telah didiskusikan. Pembelajaran yang dilaksanakan telah mampu meningkatkan hasil belajar siswa dan telah mencapai kriteria ketuntasan belajar yang diharapkan.

Dari tabel 1 dapat dilihat bahwa dengan menerapkan metode pembelajaran kooperatif tipe group investigation pada mata pelajaran PKn diperoleh nilai rata-rata ulangan harian siswa adalah 77,68 dan ketuntasan belajar mencapai $90.90 \%$ atau ada 30 siswa dari 33 siswa sudah tuntas belajar. Hasil tersebut menunjukkan bahwa pada siklus kedua secara klasikal siswa sudah tuntas belajar, karena siswa yang memperoleh nilai $\geq 70$ sebesar 90.90 $\%$. Nilai tersebut sudah melebihi dari persentase ketuntasan yang dikehendaki yaitu sebesar $85 \%$.

Siswa dapat memahami konsep-konsep materi pembelajaran dengan baik karena siswa terlibat aktif pada saat proses kegiatan belajar. Siswa mencari tahu hal-hal penting mengenai materi melalui investigasi dengan teman sekelompoknya. Hasil belajar siswa ini digunakan untuk mengetahui sejauh mana pemahaman siswa terhadap materi pembelajaran yang telah disampaikan.

Selain itu peran guru juga mempengaruhi hasil belajar siswa. Guru harus mampu menciptakan suatu lingkungan belajar yang kondusif dan memahami kesulitan yang dihadapi siswa ketika pembelajaran berlangsung. Guru harus menghindari penyajian informasi dalam bentuk ceramah karena hal ini akan mengakibatkan kurangnya partisipasi siswa dalam kegiatan pembelajaran untuk memenuhi salah satu karakteristik model yang diharapkan siswa menjadi aktif dalam mencari dan mengolah sendiri informasi.

Model

pembelajaran kooperatif dipandang sebagai proses pembelajaran yang aktif, sebab siswa akan lebih banyak belajar melalui proses pembentukan (contructing) dan penciptaan, kerja dalam kelompok dan berbagi pengetahuan serta tanggung jawab individu tetap merupakan kunci keberhasilan 
pembelajaran. Hal ini sejalan dengan pendapat Jacobs et.al (dalam Wiryandi, 2010:24) yang menyatakan konsep penting yang harus diperhatikan dalam pendekatan GI yang bersifat humanis adalah : (1) menghindarkan evaluasi yang menggunakan tes, (2) learning by doing, (3) membangun motivasi intrinsic, (4) mengutamakan pilihan siswa, (5) memperlakukan siswa sebagai orang yang bertanggungjawab, (6) pertanyaanpertanyaan terbuka, (7) mendorong rasa saling menghormati dan saling membantu, dan (8) membangun konsep diri yang positif.

Dari hasil tes ini dapat dilihat bahwa hasil belajar dengan menggunakan metode pembelajaran kooperatif tipe group investigation telah mampu meningkatkan pemahaman siswa mengenai materi pelajaran PKn sesuai dengan indikator yang telah ditentukan sehingga tidak perlu lagi dilanjutkan pada siklus berikutnya dan dikatakan berhasil. Gambaran peningkatan ketuntasan belajar yang diperoleh setelah melakukan penelitian dengan menggunakan metode kooperatif tipe group investigation terlihat pada gambar berikut:

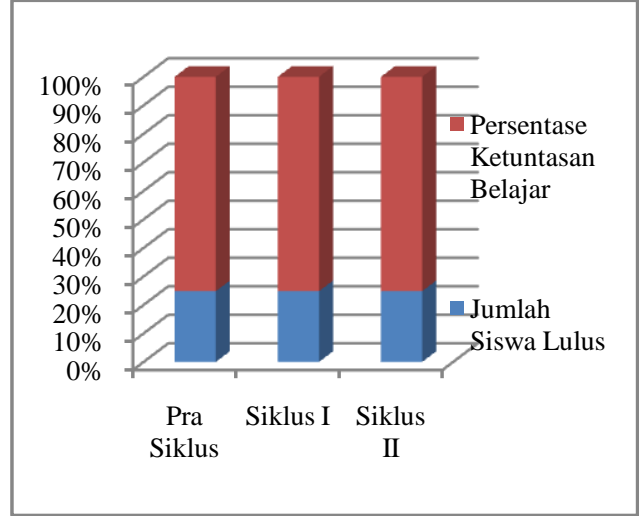

Gambar 1. Peningkatan Ketuntasan Belajar

Dilihat dari peningkatan aktivitas belajar siswa dalam pembelajaran PKn. Pada siklus I nilai rata-rata diperoleh 72dengan kualifikasi cukup aktif. Sedangkan pada siklus II nilai rata-rata yang diperoleh sebesar 77,68 dengan kualifikasi aktif. Dilihat dari pernyataan tersebut sudah terjadinya peningkatan dari siklus I ke siklus II sebesar 18,18\%. Hal ini menunjukkan penerapan model pembelajaran Group Investigation (GI) dapat meningkatkan aktivitas belajar siswa dalam mata pelajaran PKn. Penerapan model pembelajaran Group Investigation (GI) dapat digunakan sebagai salah satu upaya untuk meningkatkan aktivitas belajar siswa dalam mata pelajaran PKn.

\section{Pembahasan}

Berdasarkan hasil yang didapat dari setiap siklus proses pembelajaran yang optimal, hal ini ditunjukkan dengan meningkatnya penguasaan materi dan hasil belajar siswa. Oleh karena itu dapat disimpulkan bahwa proses pembelajaran dengan penerapan inkuiris angat sesuai dengan mata 
pelajaran PKn. maka Penelitian

Tindakan Kelas (PTK) ini bisa dikatakan berhasil karena hasil peningkatan proses pembelajarannya optimal.

\section{SIMPULAN}

Dari hasil temuan penelitian tentang hasil belajar siswa dengan metode kooperatif tipe group investigation di Kelas V SD Negeri 165730 Tebing Tinggi tahun pelajaran 2017/2018 berdampak positif dalam meningkatkan hasil belajar siswa. Hal tersebut dapat dilihat dari peningkatan persentase ketuntasan belajar siswa pada pra siklus $(66,67 \%)$, siklus I $(72,72 \%)$, siklus II $(90,90 \%)$.

\section{DAFTAR RUJUKAN}

Arikunto, Suharsimi. 1998. Prosedur Penelitian Suatu Pendekatan Praktek. Jakarta: Rineka Cipta. Ittihad, Zainul Amin. 2007. Pendidikan Kewarganegaraan. Jakarta: Universitas Terbuka.

Mikarsa, Hera Lestari, dkk. 2007. Pendidikan Anak di SD. Jakarta: Universitas Terbuka. Ruminiati. 2007. Pengembangan Pendidikan Kewarganegaraan SD. Jakarta: Depdiknas.

Wiryadi. 2010. Pengaruh Model Pembelajaran Kooperatif Tipe Group Investigation (GI) Terhadap Hasil Belajar Kimia Dengan Mempertimbangkan Kreativitas Siswa (Studi Eksperimen Terhadap Para Siswa SD Dwijendra Denpasar). Tesis. Program
Studi Penelitian dan Evaluasi Pendidikan, Undiksha. 